\title{
Immunohistochemical Expression of p16 in Pleomorphic Salivary Adenoma
}

\section{Tükürük Bezinin Pleomorfik Adenomunda İmmünohistokimyasal p16 Ekspresyonu}

\author{
Bassel TARAKJI ${ }^{1}$, Kusai BAROUDI ${ }^{2}$, Shorouk DARWISH ${ }^{3}$, Salah SAKKA ${ }^{4}$, Salah HANOUNEH ${ }^{5}$ \\ ${ }^{1}$ Department of Oral Pathology, Aleppo University, Faculty of Dentistry, SYRIA, ${ }^{2}$ Department of Pediatric Dentistry, Al-Baath University, Faculty of Dentistry, SYRIA, \\ Department of ${ }^{3}$ Applied Science and ${ }^{4}$ Oral Surgery, Alfarabi College of Dentistry, RIYADH, KINGDOM of SAUDI ARABIA, \\ ${ }^{5}$ Supervisor for Academic and Educational Affairs
}

\begin{abstract}
Objective: This study aimed to characterize alteration in the immunohistochemical expression of p16 in normal tissue of the salivary gland surrounding pleomorphic adenoma, and the tumor cells of pleomorphic adenomas.

Material and Method: A selected series of 120 cases of pleomorphic adenomas were examined.

Results: The results showed that p16 expression in non tumor duct cells was strong positive nuclear staining in $98(81.6 \%)$ cases out of 120 , while there were $20(16.6 \%)$ with moderate staining, and 2 (1.6\%) with weak staining in the components of normal tissue of the salivary gland surrounding pleomorphic adenoma. p16 expression in pleomorphic adenomas showed $71(59.1 \%)$ cases with moderate nuclear staining in the duct cells, 45 (37.5\%) cases with nuclear weak staining, and $4(3.3 \%)$ cases with negative staining. p16 nuclear staining in myxochondroid tissue was identified in $4(3.3 \%)$ cases with strong staining, $65(54.1 \%)$ cases had moderate staining, and 51 $(42.5 \%)$ cases had weak staining.
\end{abstract}

Conclusion: This study suggests alteration of p16 expression in pleomorphic adenomas. P16 might have a role in the development of pleomorphic adenoma.

Key Words: Cyclin-dependent kinase inhibitor p16, Immunohistochemistry, Pleomorphic adenoma

\section{ÖZ}

Amaç: $\mathrm{Bu}$ çalışmada tükrük bezinin pleomorfik adenomunda ve normal dokuda p16 immünohistokimyasal ekspresyonu araştırılmıştır.

Gereç ve Yöntem: 120 pleomorfik adenoma olgusu çalışılmıştır.

Bulgular: Pleomorfik adenoma çevresindeki normal duktal hücrelerde 98 olguda kuvvetli $(\% 81,6), 20$ olguda orta şiddette $(\% 16,6)$ ve 2 olguda zayıf $(\% 1,6)$ nükleer p16 ekspresyonu saptandı. Pleomorfik adenomda duktal hücrelerde 71 olguda orta şiddette $(\% 59,1), 45$ olguda zayıf $(\% 37,5)$ ve 4 olguda negatif $(\% 3,3)$ p16 nükleer ekspresyonu gözlendi. Mikzokondroid dokuda ise 4 olguda kuvvetli $(\% 3,3), 65$ olguda orta şiddette $(\% 54,1)$ ve 51 olguda zayıf $(\% 42,5)$ boyanma elde edildi.

Sonuç: Bu çalışma, pleomorfik adenomlarda p16 ekspresyonunda değişiklik olduğunu göstermektedir. Pleomorfik adenom gelişiminde p16'nın rolü olabilir.

Anahtar Sözcükler: Siklin bağımlı kinaz inhibitörü p16, İmmünohistokimya, Pleomorfik adenom

the 9p21 region, acts as a negative cell cycle regulator (1). Specific mechanisms may contribute to p16 altered expression, overcoming p16-mediated tumor suppressor activities. Protein p16 is a negative regulator of the cell cycle and is the product of the cyclin dependent kinase 2 (CDKN2) gene. Studies of the molecular genetics of oral cancer have shown that the CDKN2 gene was frequently inactivated by methylation or homozygous deletion (1).

Correspondence: Tarakji BASSEL

Department of Oral Pathology, Aleppo University, Faculty of Dentistry,

SYRIA

E-mail: denpol@yahoo.co.uk Phone: +96650462 3330 
Inactivation of p16 (INK4a), encoded by the CDKN2 gene has been widely associated with oral squamous cell carcinomas (2). p16 is a cyclin dependent kinase inhibitor that binds to CDK4 and forms a p16-CDK4 complex, which prevents phosphorylation of the product of the retinoblastoma susceptibility gene $\mathrm{pRb}$, and $\mathrm{pRb}$ remains in an hypophosphorylated, growth suppressive state. In the case of dysfunction of p16, CDK4 can bind to cyclin D and form a CDK4-cyclin $\mathrm{D}$ complex. This complex promotes the phosphorylation of $\mathrm{pRb}$ and the release of a transcriptional factor, which accelerates the cell cycle. Inactivation of p16 therefore leads to deregulation of the cell cycle control and to cell proliferation (3-4). Perturbation of this cell cycle regulatory pathway by tumor-specific genetic alteration or by inactivation of $\mathrm{p} 16$ or $\mathrm{pRb}$ or overexpression of CDK4 or cyclin D1 has been shown in many human cancers (5). Loss of p16 function by gene deletion, methylation and mutation within the reading frame have been found in various cancers (6-7).

Pleomorphic adenoma (PA) is the most common neoplasm of salivary glands (8) and has shown sometimes tendency to undergo malignant transformation in its natural course (910). The etiology of PA is unknown. It is of epithelial origin and clonal chromosome abnormalities with aberrations involving 8q12 and 12q15 have been described (11). The pathogenetic mechanisms involved in the progression of pleomorphic adenoma to a carcinoma remain unclear, requiring evaluation of molecular events in pleomorphic adenoma. The purpose of this study was to determine the alterations in the immunohistochemical expression of p16 in normal tissue of the salivary gland surrounding pleomorphic adenoma, and the tumor cells of pleomorphic adenomas.

\section{MATERIAL and METHODS}

A selected series of 120 cases of pleomorphic adenomas (66 female, 54 male) were retrieved from the files of two Oral Pathology Departments in Aleppo, and Alfarabi Dental School. Normal tissue of the salivary gland surrounding the tumor was used as a control. Immunohistochemical expression against p16 was examined in the selected cases. Microscopic slides stained with hematoxylin and eosin were reviewed by two pathologists to confirm the histopathological diagnosis and to reclassify the studied cases. The ethical approval was provided from research ethics committee (Ref: 06/1012).

Paraffin-embedded tumor samples stored in pathology laboratory files were used in this study. Serial $4 \mu \mathrm{m}$ sections were consecutively cut from all 120 specimens. The sections were deparaffinized in xylene and rehydrated through graded alcohols. Sections were processed used streptavidinbiotin-peroxidase method. Briefly, the endogenous peroxidase was blocked by $3 \%$ hydrogen peroxidase for $5 \mathrm{~min}$ followed by TBS (Tris buffered saline) wash. Nonspecific immunoreactivity was blocked by incubation with normal goat serum for 20 minutes. A purified mouse anti-human monoclonal antibody p16 (Pharmingen, San Diego) was diluted to $5 \mathrm{~m} / \mathrm{ml}$ in $10 \mathrm{~m} / \mathrm{ml}$ tris buffer saline containing $0.1 \%$ bovine serum albumin for 1 hour at room temperature. All sections were washed by TBS for 5 minutes. Sections were incubated with the biotinylated secondary antibody reagent for 30 minutes followed by TBS wash for 5 minutes. Slides were incubated with streptavidin and horseradish peroxidase for 30 minutes followed by TBS wash for 5 minutes and incubated with a prepared chromogenic substrate solution (Diaminobenizidine) for 15 minutes. Sections were counterstained with $0.25 \%$ methyl green in distilled water for 5 minutes. Sections were dehydrated and mounted in Depax. Squamous cell carcinoma was used as positive control. Negative control was used only with substitution the primary antibody with TBS. The staining pattern was classified according to the relative number of positive cells in the different epithelial layers of the specimens. A brown precipitate seen within the nucleus confirmed the presence of protein. A total of five areas was chosen randomly from each of the tested slides and scored at high power magnification. The nuclear staining was observed exclusively in the nuclei of the test cells. None of the negative controls displayed brown staining in the test cells. The percentage of p16 positive nuclei was semiquantitatively assessed by two independent observers and scored as: negative ( 0 ) no expression of nuclear protein, weak staining (1) $0-25 \%$ of the total cells shows positive staining in the nucleus, moderate staining (2) $>25-75 \%$ of the total cells in the test area show positive nuclear staining, strong staining (3) $>75-100 \%$ cells show positive nuclear staining.

The statistical analysis included the use of descriptive statistics, frequencies proportion and crossed tabulation. Also, statistical analyses, including Wilcoxon's nonparametric tests (ordinal data), were performed on the data. All statistical tests were two-sided and $p$-values less than 0.05 were considered to be statistically significant.

\section{RESULTS}

p16 expression of the nuclear staining was studied in an adjacent area of the pleomorphic adenoma. The results (nuclear staining of duct cells) indicated that p16 showed strong positive nuclear staining in $98(81.6 \%)$ cases out of 
120 , together with $20(16.6 \%)$ with moderate staining, and $2(1.6 \%)$ with weak staining.

p16 nuclear staining of the acinar cells showed negative staining in $3(2.5 \%)$ cases out of 120 , and there were 40 (33.3\%) with weak staining, and 77 (64.1\%) with moderate staining.

p16 nuclear staining in the stroma was observed in 10 $(8.3 \%)$ cases out of 120 with moderate staining, and 110 $(91.6 \%)$ cases had weak staining.

p16 expression of the nuclear staining was studied in an adjacent area of the pleomorphic adenoma. The existence of p16 positive expression was higher in non duct tumor cells than acinar cells. p16 expression in normal salivary glands (duct cells) surrounding the pleomorphic adenoma were significantly different from p16 expression in acinar cells (normal salivary glands) $(\mathrm{p}<0.001)$. In non tumor duct cells, p16 strong staining was present in $98(81.6 \%)$ cases out of 120 , and there were $20(16.6 \%)$ with moderate staining, and $2(1.6 \%)$ with weak staining. p16 nuclear staining of the acinar cells showed negative staining in $3(2.5 \%)$ cases out of 120 , together with $40(33.3 \%)$ with weak staining, and 77 $(64.1 \%)$ with moderate staining.

p16 nuclear staining with moderate staining was noted in tumor duct cells in 71 (59.1\%) cases out of 120 (Figure 1), while $45(37.5 \%)$ cases showed weak staining (Figure 2), and $4(3.3 \%)$ cases showed negative staining.

p16 nuclear staining in myxochondroid tissue was identified in $4(3.3 \%)$ cases with strong staining, while $65(54.1 \%)$ cases had moderate staining, and $51(42.5 \%)$ cases had weak staining. The results indicated reduced p16 expression in the nucleus of tumor duct cells and myxochondroid tissue. There was no significant difference between p16 expression in the nucleus of myxochondroid and tumor duct cells.

Comparison between staining of different components in pleomorphic adenoma and the adjacent tissue around tumor showed a significant difference between p16 expression in both duct cells of normal tissue surrounding the tumor and the tumor area itself $(\mathrm{p}<0.001)$. In normal tissue, $\mathrm{p} 16$ expression of the duct cells showed strong positive nuclear staining in $98(81.6 \%)$ cases out of 120 , together with 20 (16.6\%) with moderate staining, and $2(1.6 \%)$ with weak staining but in tumor duct cells, 71 (59.1\%) cases out of 120 showed moderate staining, while 45 (37.5\%) cases showed weak staining, and $4(3.3 \%)$ cases negative staining.

\section{DISCUSSION}

p16 was expressed in the nucleus of duct and acinar cells of normal salivary glands but it is possible that the normal

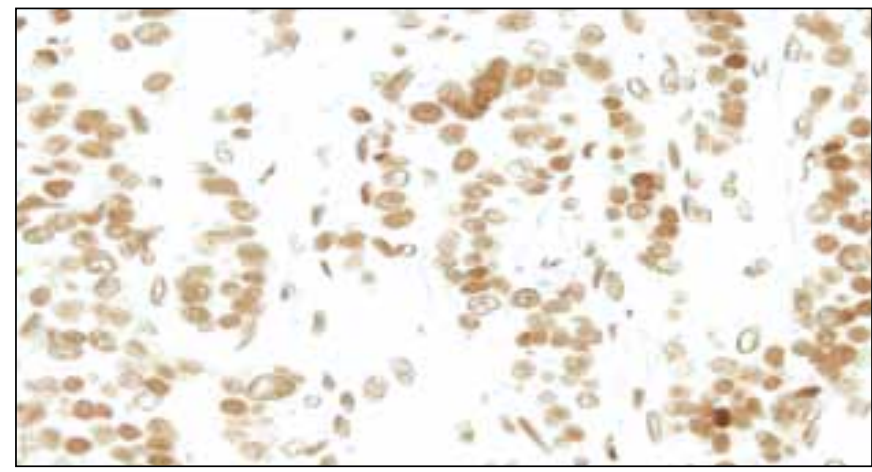

Figure 1: Moderate nuclear staining of p16 in pleomorphic salivary adenoma (H\&E, x40).

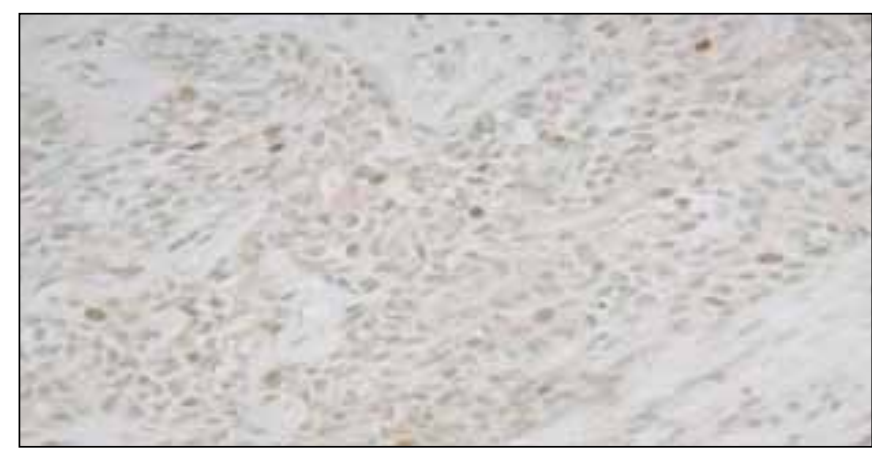

Figure 2: Low nuclear staining of p16 in pleomorphic salivary adenoma (H\&E, x40).

duct cell proliferation rate is higher than that of acinar cells because 98 cases out of 120 showed positive strong nuclear staining in normal duct cells but did not show strong positive staining in the acinar cells. Zhu et al. indicated that the current histogenic theory of salivary gland tumourigenesis considered the acinar cells as functionally mature cells and suggested that the acinar cells were terminally differentiated and incapable of further proliferation (12). Also, this theory considered that proliferation for the purpose of repair and regeneration was confined to stem cells residing exclusively amongst luminally located intercalated duct cells or basally located excretory duct cells.

Zhu et al. used proliferating cell nuclear antigen (PCNA) immunostaining in normal parotid gland and identified low numbers of PCNA positive cells in acinar, ductal luminal cells and myoepithelial cells from both acini and the duct system (12). Therefore, they suggested that any of the epithelial cell types present in normal salivary gland are capable of proliferation and have the potential to give rise to the variant tumor cell types arising in salivary gland tumors.

P16 expression in pleomorphic adenoma showed that the incidence of aberrant expression of these proteins 
was higher in tumor duct cells than in myxochondroid tissue. Although p16 showed alteration in expression in myxochondroid tissue, there is evidence that cells in myxochondroid tissue show low levels of proliferation (13).

Nielsen et al. reported that p16 showed positive staining in the duct and acinar cells of salivary glands (14). Shintani et al. have studied the alterations of pRb, p16 and cyclin D1 in adenoid cystic carcinoma of salivary glands (15). In normal salivary glands, $\mathrm{pRb}$ protein was observed in the nucleus of duct cells and myoepithelial cells. p16 protein was expressed in normal salivary glands (myoepithelial, and duct cells). There was no positive staining of $\mathrm{pRb}$ or $\mathrm{p} 16$ in the acinar cells of normal salivary glands. $\mathrm{Hu}$ et al. investigated the p16 protein expression and promoter methylation of p16 gene in carcinoma ex pleomorphic adenoma and their roles in the malignant transformation of pleomorphic adenoma to carcinoma ex pleomorphic adenoma (6). They found no correlation between p16 protein expression and promoter methylation of the p16 gene in either benign or malignant components. Schache et al. demonstrated the successful application of quantitative methylation-specific real-time polymerase chain reaction (qMSP) analysis to a large series of historical carcinoma ex pleomorphic adenoma samples and reported on a panel of tumour suppressor genes with significant differences in their methylation profiles between benign and malignant variants of pleomorphic salivary adenoma (16). They concluded that qMSP analysis could be developed as a useful clinical tool to differentiate between carcinoma ex pleomorphic adenoma and its benign precursor.

Patel et al. have examined cyclin D1 and p16 expression in 43 parotid tumours (29 pleomorphic salivary adenoma and 14 carcinoma ex pleomorphic (17). They indicated that Cyclin D1 and p16 were both significantly more likely to be expressed in the neoplastic than in the normal epithelial and stromal components of pleomorphic adenoma and carcinoma ex pleomorphic adenoma $(\mathrm{p}<0.001$, and $\mathrm{p}<0.005$, respectively).

Augello et al. reported that p16(INK4A) promoter hypermethylation was found in $14 \%$ (4/28) of pleomorphic adenoma and $100 \%(5 / 5)$ carcinomas including of 4 cases of cystic adenocarcinomas, and 1 case of carcinoma ex pleomorphic adenoma (18). Gong et al. reported that positive rate of P16 protein expression was $76.9 \%$ (10/13) and $40.9 \%(9 / 22)$ in benign and malignant salivary gland tumors, respectively (19). Weber et al. indicated that the alterations of p16 (INK4a) occurred in 12/42 of pleomorphic adenomas, which correlated with loss of mRNA transcription (20). They also noticed that alterations of p14(ARF), p16(INK4a), and also p53 mutations occurred exclusively in the epithelial and transitional components of pleomorphic adenoma, supporting the theory that these areas are prone to malignant transformation to carcinoma in adenoma.

When weak, negative nuclear staining was considered as the only indicator for existing altered p16, and the positive moderate and strong p16 nuclear staining was considered as an indicator for existing normal expression of p16. The results would show p16 was negative in 49 (40.8\%) out of 120 cases of pleomorphic adenomas (tumor duct cells). These differences may have resulted from the following reasons: The use of different antibodies, different evaluations of staining, fixation times and concentrations of antibodies, and the sensitivity of the technique used. If only negative staining (p16) was used as indicator for the alteration in the expression of tumor suppressor protein, then alteration in expression of p16 was detected in 49 (40.8\%) out of 120 cases of pleomorphic adenomas (tumor duct cells). The assessment of the positive or negative nuclear staining is controversial. Many authors used different criteria so the results cannot be compared. In the present study, the use of negative and positive staining for the assessment of staining avoided any confusion in the interpretation of the results. The immunostaining technique is used only combined with another technique such as Polymerase Chain Reaction or Western Blotting to detect and confirm the existence of a mutation. Unfortunately, we did not use any other technique to confirm the immunostaining results that is recommended for further studies. Many studies used criteria such as negative, low, moderate, and strong staining. This study comprised 120 cases of pleomorphic adenoma that is much bigger than other published studies. The conclusion of this study is that the alteration of p16 expression has been detected in pleomorphic adenoma cases. P16 might have a role in the development of pleomorphic adenoma. Further research oriented to extract DNA from the studied cases to detect mutations as a probable main cause of inactivation and to identify other causes of inactivation such as methylation or loss of heterozygosity is recommended.

\section{REFERENCES}

1. Kashiwabara K, Tetsunari O, Takaaki S, Toshio F, Takashi N: Correlation between methylation status of the p16/CDKN2 gene and the expression of $\mathrm{p} 16$ and $\mathrm{Rb}$ proteins in primary non small cell lung cancers. Int J Cancer 1998, 79: 215-220

2. Pérez-Sayáns M, Suárez-Peñaranda JM, Gayoso-Diz P, BarrosAngueira F, Gándara-Rey JM, García-García A: p16(INK4a)/ CDKN2 expression and its relationship with oral squamous cell carcinoma is our current knowledge enough. Cancer Lett 2011, 306:134-141 
3. Koh VM, Shi YX, Tang QH: P16 and retinoblastoma protein expression in endometrial carcinoma and clinical significance. Eur J Gynaecol Oncol 2011, 32:309-315

4. Fernandez PL, Jares P, Rey M.J, Campo E, Cardesa A: Cell cycle regulators and their abnormalities in breast cancer. Mol Pathol 1998, 51: 305-309

5. Ueki K, Ono Y, Henson JW, Efird JT, von Deimling A, Louis DN: CDKN2/p16 or RB alterations occur in the majority of glioblastomas and are inversely correlated. Cancer Res 1996, 56:150-153

6. Hu YH, Zhang CY, Tian Z, Wang LZ, Li J: Aberrant protein expression and promoter methylation of p16 gene are correlated with malignant transformation of salivary pleomorphic adenoma. Arch Pathol Lab Med 2011, 135:882-889

7. Kobayashi N, Toyooka S, Yanai H, Soh J, Fujimoto N, Yamamoto H, Ichihara S, Kimura K, Ichimura K, Sano Y, Kishimoto T, Date $H$ : Frequent p16 inactivation by homozygous deletion or methylation is associated with a poor prognosis in Japanese patients with pleural mesothelioma. Lung Cancer 2008, 62: 120-125

8. Ungari C, Paparo F, Colangeli W, Iannetti G: Parotid glands tumours: Overview of a 10-year experience with 282 patients, focusing on 231 benign epithelial neoplasms. Eur Rev Med Pharmacol Sci 2008, 12:321-325

9. Demasi AP, Furuse C, Soares AB, Altemani A, Araújo VC, Peroxiredoxin I: Platelet-derived growth factor A, and plateletderived growth factor receptor alpha are overexpressed in carcinoma ex pleomorphic adenoma: Association with malignant transformation. Hum Pathol 2009, 40: 390-397

10. Suzuki H, Yasunori F: Deletion of the CDKN2A gene and microsatelltie instability of the parotid gland. Diagn Mol Pathol 1998, 7: 224-331

11. Li X, Tsuji T, Wen S, Mimura Y, Sasaki K, Shinozaki F: Detection of numeric abnormalities of chromosome 17 and p53 deletions by fluorescence in situ hybridization in pleomorphic adenomas and carcinomas in pleomorphic adenoma. Correlation with p53 expression. Cancer 1997, 79:2314-2319
12. Zhu Q, White FH, Tipoe GL: The assessment of proliferating cell nuclear antigen (PCNA) immunostaining in human benign and malignant epithelial lesions of the parotid gland. Oral Oncol 1997, 33:29-35

13. Zhu Q, Tipoe GL, White FH: Proliferative activity as detected by immunostaining with $\mathrm{Ki}-67$ and proliferating cell nuclear antigen in benign and malignant epithelial lesions of the human parotid gland. Anal Quant Cytol Histol 1999, 21:336-342

14. Nielsen GP, Stemmer-Rachamimov AO, Shaw J, Roy JE, Koh J, Louis DN: Immunohistochemical survey of p16INK4A expression in normal human adult and infant tissues. Lab Invest 1999, 79:1137-1143

15. Shintani S, Mihara M, Nakahara Y, Kiyota A, Yoshihama Y, Ueyama Y, Matsumura T: Infrequent alternations of RB pathway (Rb-p16INK4A-cyclinD1) in adenoid cystic carcinoma of salivary glands. Anticancer Res 2000, 20:2169-2175

16. Schache AG, Hall G, Woolgar JA, Nikolaidis G, Triantafyllou A, Lowe D, Risk JM, Shaw RJ, Liloglou T: Quantitative promoter methylation differentiates carcinoma ex pleomorphic adenoma from pleomorphic salivary adenoma. Br J Cancer 2010, 103: 1846-1851

17. Patel RS, Rose B, Bawdon H, Hong A, Lee CS, Fredericks S, Gao $\boldsymbol{K}$, O'Brien CJ: Cyclin D1 and p16 expression in pleomorphic adenoma and carcinoma ex pleomorphic adenoma of the parotid gland. Histopathology 2007, 51:691-696

18. Augello C, Gregorio V, Bazan V, Cammareri P, Agnese V, Cascio S, Corsale S, Calò V, Gullo A, Passantino R, Gargano G, Bruno L, Rinaldi G, Morello V, Gerbino A, Tomasino RM, Macaluso M, Surmacz E, Russo A: TP53 and p16INK4A, but not H-KI-Ras, are involved in tumorigenesis and progression of pleomorphic adenomas. J Cell Physiol 2006, 207:654-659

19. Gong L, Chen ZL, Hu J, Huo HY: Expression of p16 and nm23 genes in salivary gland tumors. Hua Xi Kou Qiang Yi Xue Za Zhi 2004, 22:155-157

20. Weber A, Langhanki L, Schütz A, Wittekind C, BootzF, Tannapfel $A$ : Alterations of the INK4a-ARF gene locus in pleomorphic adenoma of the parotid gland. J Pathol 2002, 198:326-334 